\title{
Poorly humified peat as an adsorbent for metals in wastewater
}

\author{
L. Ringqvist ${ }^{\mathrm{a}}$, A. Holmgren ${ }^{\mathrm{b}}$, I. Öborn ${ }^{\mathrm{c}, *}$ \\ ${ }^{a}$ Department of Agricultural Research for Northern Sweden, Swedish University of Agricultural Sciences, P.O. Box 4097, \\ SE-904 03 Umeå, Sweden \\ ${ }^{\mathrm{b}}$ Division of Inorganic Chemistry, Department of Chemical and Metallurgical Engineering, Lulea University of Technology, \\ SE-971 87 Luleå, Sweden \\ ${ }^{\mathrm{c}}$ Department of Soil Sciences, Swedish University of Agricultural Sciences, P.O. Box 7014, SE-750 07 Uppsala, Sweden
}

Received 15 May 2000; received in revised form 23 August 2001; accepted 21 September 2001

\begin{abstract}
Metal adsorption and surface charge determinations were performed previously on well-characterised Sphagnum and Carex peat samples. The aim of this investigation was to determine metal adsorption from complex wastewaters onto these peat samples and compare it to the adsorption onto peat granules, clinoptilolite, glauconite and a flue dust from steel production. A sulphide mine leachate, a landfill leachate and a laundry wastewater were chosen, giving a variation in $\mathrm{pH}$, ionic strength, total organic carbon and concentrations of metals. Metal adsorption was determined in batch and column experiments. The wastewater composition was of great importance for metal removal efficiency, mainly due to the difference in dominating metal species. In the sulphide mine leachate, containing free metal ions, a high metal adsorption was observed onto both peat and inorganic adsorbents. In the landfill leachate the metals formed carbonate and organic complexes and a low metal removal was achieved. Contrary to the leachates, the laundry wastewater contained suspended particles. The high amount of metals removed, $80 \%$ of the $\mathrm{Cu}$ and $30-60 \%$ of the $\mathrm{Zn}$ concentration, was probably withdrawn bound to the particle fraction. The highest removal of metal ions was obtained in the sulphide mine leachate with Carex peat, removing $97-99 \%$ of the $\mathrm{Zn}$ and $85-100 \%$ of the $\mathrm{Cu}$ content. The Sphagnum peat sample removed $37-77 \%$ of the $\mathrm{Zn}$ and $80-100 \%$ of the $\mathrm{Cu}$ content. The differences found between Sphagnum and Carex peat were attributed to the original chemistry of the plant material and the habitat conditions at the time of peat formation. Generally, the combination of glauconite or clinoptilolite with the peat samples in column experiments gave a minor improvement in metal removal. (C) 2002 Elsevier Science Ltd. All rights reserved.
\end{abstract}

Keywords: Sphagnum peat; Carex peat; Wastewater; Heavy metals; Adsorption

\section{Introduction}

Sources of heavy metal contamination can be found in landfills and mine waste deposits, from which metals can leach for very long periods of time. Peat is a cheap product which is available in many areas, and which has the ability to adsorb heavy metals. Metal adsorption from municipal, industrial and mine deposits onto peat have been investigated previously [1-6]. Lidkea [3]

\footnotetext{
*Corresponding author. Tel.: + 46-18-671274; fax: +46-18672795 .

E-mail address: ingrid.oborn@mv.slu.se (I. Öborn).
}

reports an adsorption capacity of $48 \mathrm{mg} \mathrm{g}^{-1}$ for fibric (mainly Sphagnum) peat. Rock et al. [4] write "peat seems to have a great potential in the treatment of heavy metals, pesticides, and other toxic materials and may be especially adaptable to the treatment of leachate". That authors also found that leachate odour was decreased after filtration through peat. Problems with clogging during filtration of municipal leachate have been reported by McLellan and Rock [7] and Lyons and Reidy [6]. Parameters influencing metal adsorption from wastewater are metal concentration in the solution, ionic strength, pH, and complex-forming substances. Mechanisms other than adsorption, such as precipitation 
and mechanical entrapment, are involved in treating complex wastewaters [1,2]. Previously it was found that Sphagnum peat adsorbed a higher amount of $\mathrm{Cu}$ compared to Carex peat at $\mathrm{pH} 4.7$ [8]. The surface charge density was found to be higher on Sphagnum peat than on Carex peat in the $\mathrm{pH}$ interval 4.5-5.5 [9]. It was further found that absorption of $\mathrm{Zn}$ in particular but also of $\mathrm{Cu}$ increased more with the $\mathrm{pH}$ value on Carex peat than on Sphagnum peat, giving a higher metal adsorption onto Carex peat at high $\mathrm{pH}$ values [10].

Fine dust, produced in large quantities in the steel production at SSAB in Luleå, has been found to be a potential adsorbent for metals. Copper, lead, zinc, cadmium and chromium were removed from solutions by surface adsorption in the $\mathrm{pH}$ range $5.5-11.5$ [11]. The natural zeolite, clinoptilolite, is used in applications such as chemical filters, odour control and filters for municipal and drinking water. Clinoptilolite adsorbs ammonium ions from leachate [12], but also metal ions $[13,14]$. Glauconite, a three-layer sheet aluminosilicate, has been found to reduce heavy metal cations, lessen unpleasant odour and diminish murkiness of landfill leachate $[15,16]$.

Metal adsorption $[8,10]$, and surface charge determinations [9] have previously been performed on wellcharacterised [17] Sphagnum and Carex peat samples. The aim of this investigation was to determine metal adsorption from complex wastewaters onto these peat samples and compare it to the adsorption onto peat granules and inorganic adsorbents, i.e. clinoptilolite, glauconite and a residue from steel production. A sulphide mine leachate, a landfill leachate and a laundry wastewater were chosen, giving a variation in
$\mathrm{pH}$, ionic strength, total organic carbon and metal concentrations.

\section{Materials}

\subsection{Adsorbents}

Sphagnum and Carex peat samples previously used in metal adsorption experiments $[8,10]$ and surface charge determinations [9] were used in this study (Table 1). The samples were untreated in this study and in studies performed by Fattahpour Sedeh [8] and Bergner et al. [9] while acid washed samples were used by Ringqvist and Öborn [10]. Poorly humified peat samples, humification degree 2-4 according to the von Post scale (ranging from 1 to 10), were chosen. Poorly humified peat has a coarser structure than highly humified peat, which gives sufficient permeability in column experiments. The botanical origin of the peat samples was previously found $[9,8]$ to be more important for metal adsorption than the humification degree. Two Sphagnum peat samples of different sections, and one Carex peat sample (Table 1) were chosen in this study. A peat pellet with unknown botanical origin and humification degree was used as well. The Sphagnum peat samples chosen were peat formed by the Sphagna sect. Cuspidata, growing in pools or in very low areas on the mire and the Sphagna sect. Acutifolia, forming hummocks. A higher CEC in the Acutifolia group of Sphagnum mosses has been reported compared to the Sphagna sect. Cuspidata. The difference was correlated to the uronic acid content in the moss $[19,20]$. The same pattern has also been

Table 1

Peat samples used in the experiments ${ }^{\mathrm{a}}$

\begin{tabular}{|c|c|c|c|}
\hline & $\begin{array}{l}\text { Sphagna sect. } \\
\text { Acutifolia peat }\end{array}$ & $\begin{array}{l}\text { Sphagna sect. } \\
\text { Cuspidata peat }\end{array}$ & Carex peat \\
\hline Sample code & SF06 & Su39 & AD04 \\
\hline Botanical composition (\%) & $\mathrm{S}_{92}$ & $\mathrm{~N}_{5} \mathrm{Gr}_{10} \mathrm{~S}_{82}$ & $\mathrm{C}_{98}$ \\
\hline Composition of Sphagna (\%) & $\mathrm{Pa}_{10} \mathrm{Ac}_{66}$ & $\mathrm{Cu}_{74}$ & - \\
\hline Humification degree (von Post) & 3 & $2-3$ & $2-3$ \\
\hline Ash content ( $\%$ of dry matter) & 1.2 & 1.5 & 6 \\
\hline Uronic acid $(\%)$ & $14-17$ & not measured & 6 \\
\hline Klason lignin $(\%)$ & $18-29$ & 39 & $53-56$ \\
\hline $\mathrm{Fe}\left(\mathrm{mmol} \mathrm{kg}^{-1}\right)$ & 31 & 36 & 290 \\
\hline $\mathrm{Ca}\left(\mathrm{mmol} \mathrm{kg}^{-1}\right)$ & 41 & 80 & 175 \\
\hline $\mathrm{Cu}\left(\mathrm{mmol} \mathrm{kg}^{-1}\right)$ & $<0.13$ & 0.04 & 0.05 \\
\hline $\mathrm{Zn}\left(\mathrm{mmol} \mathrm{kg}^{-1}\right)$ & 0.09 & 0.08 & 0.04 \\
\hline Surface charge, Bergner et al. [9], $\left(\operatorname{mmol}(+) \mathrm{g}^{-1}\right)$ & 0.48 & 0.38 & 0.12 \\
\hline \multicolumn{4}{|c|}{ Langmuir equation for $\mathrm{Cu}$ adsorption, Fattahpour Sedeh [8] } \\
\hline Constant & 0.0589 & not measured & 0.0316 \\
\hline$(x / m)_{\max }\left(\mathrm{mg} \mathrm{g}^{-1}\right)$ & 42.6 & not measured & 30.2 \\
\hline
\end{tabular}

\footnotetext{
${ }^{\mathrm{a}} \mathrm{S}=$ Sphagnum mosses, $\mathrm{Pa}=$ Sphagna sect. Palustria, Ac $=$ Sphagna sect. Acutifolia, $\mathrm{Cu}=$ Sphagna sect. Cuspidata, $\mathrm{N}=$ Ericaceous dwarf shrubs, $\mathrm{Gr}=$ Poaceae and herbaceous plants, $\mathrm{C}=$ Cyperaceae (e.g. Carex spp.); botanical composition according to Bohlin [18]; index are percentage contained in the sample.
} 
observed in peat [21]. Further description of the peat samples used in this investigation can be found elsewhere, using the sample codes [22]. Due to different demands on the habitat for the peat-forming plants, Carex peat generally has higher ash content than Sphagnum peat (Table 1).

Inorganic adsorbents included for comparison with the peat were clinoptilolite, glauconite and a residue from steel production at SSAB in Luleå. The SSAB residue consists of flue dust collected in scrubbers in the wet gas cleaning plants. About 84000 tonnes are produced every year in Sweden. The dust contains $57 \% \mathrm{Fe}, 12 \% \mathrm{CaO}$ and $3 \% \mathrm{MgO}$, with the most prevalent phase of $\mathrm{Fe}$ in the form of $\mathrm{FeO}$ [11]. An untreated sample of the natural zeolite clinoptilolite, $80 \%$ purity, as well as an untreated sample of the threelayer sheet aluminosilicate glauconite were used in the study.

\subsection{Wastewater}

The wastewaters used were leachate from an industrial landfill, leachate from a mining area, and wastewater from a laundry (Table 2). The industrial landfill Dåvamyran, situated near Umeå, has been used since 1974 for industrial and building refuse as well as ash and cinder. Samples were collected in December 1995 and in December 1996. The landfill leachate was characterised by a high ionic strength and relatively low heavy metal content and a $\mathrm{pH}$ value of 7.8. All batch experiments were performed with the sample collected in 1995, while the column experiments were performed with the sample collected in 1996. The mining leachate originated from Laver, a closed copper mine in northern Sweden, where mining activities started in 1936 and ended in 1946. Around 1.2 million tonnes of tailings were deposited close to the mine [24]. Leachate was collected in 1995.

Table 2

Initial concentration $\left(\mathrm{m} \mathrm{L} \mathrm{L}^{-1}\right)$ of main elements and heavy metals in leachate from the sulphide mine area Laver (samples collected in Dec 1995), Dåvamyran landfill (samples collected Dec 1995 and Dec 1996) and wastewater from the KM-laundry in Gammelstad (samples from two occasions in Dec 1995

\begin{tabular}{|c|c|c|c|c|c|}
\hline & \multirow{2}{*}{$\begin{array}{l}\text { Sulphide mine } \\
\text { leachate }\end{array}$} & \multicolumn{2}{|c|}{ Landfill leachate } & \multicolumn{2}{|c|}{ Laundry wastewater } \\
\hline & & Dec 1995 & Dec 1996 & Sample 1 & Sample 2 \\
\hline $\mathrm{Ca}$ & 13.5 & 173 & 247.2 & 51.1 & 13.1 \\
\hline $\mathrm{Fe}$ & 0.8 & 2.2 & 3.5 & 6.98 & 5.25 \\
\hline K & 1.7 & 652 & 679 & 26.8 & 9.0 \\
\hline $\mathrm{Mg}$ & 2.3 & 59.6 & 49.6 & 8.4 & 2.3 \\
\hline $\mathrm{Na}$ & 2.3 & 1145 & 1140 & 839 & 362 \\
\hline $\mathrm{Al}$ & 0.3 & 0.2 & 0.01 & 3.35 & 2.74 \\
\hline $\mathrm{Mn}$ & 0.4 & 0.2 & 0.3 & 0.187 & 0.161 \\
\hline $\mathrm{Ba}$ & 0.01 & 0.2 & - & 0.309 & 0.086 \\
\hline $\mathrm{Zn}$ & $298 \times 10^{-3}$ & $53.5 \times 10^{-3}$ & $94.7 \times 10^{-3}$ & $1650 \times 10^{-3}$ & $1080 \times 10^{-3}$ \\
\hline $\mathrm{Cu}$ & $70.9 \times 10^{-3}$ & $21.6 \times 10^{-3}$ & $45.0 \times 10^{-3}$ & $1210 \times 10^{-3}$ & $715 \times 10^{-3}$ \\
\hline $\mathrm{Co}$ & $2.9 \times 10^{-3}$ & $7.4 \times 10^{-3}$ & $8.4 \times 10^{-3}$ & $11.7 \times 10^{-3}$ & $7.41 \times 10^{-3}$ \\
\hline $\mathrm{Ni}$ & $3.4 \times 10^{-3}$ & $39.1 \times 10^{-3}$ & $56.2 \times 10^{-3}$ & $132 \times 10^{-3}$ & $88.6 \cdot 10^{-3}$ \\
\hline $\mathrm{Cr}$ & $<0.500 \times 10^{-3}$ & $25.4 \times 10^{-3}$ & $54.2 \times 10^{-3}$ & $210 \times 10^{-3}$ & $141 \times 10^{-3}$ \\
\hline $\mathrm{Cd}$ & $0.8210^{-3}$ & $0.7 \times 10^{-3}$ & $0.6 \times 10^{-3}$ & $11.0 \times 10^{-3}$ & $5.40 \times 10^{-3}$ \\
\hline $\mathrm{Pb}$ & $0.6 \times 10^{-3}$ & $3.1 \times 10^{-3}$ & $2.4 \times 10^{-3}$ & $424 \times 10^{-3}$ & $233 \times 10^{-3}$ \\
\hline $\mathrm{Hg}$ & $<0.200 \times 10^{-3}$ & $0.25 \times 10^{-3}$ & n.m. & $1.38 \times 10^{-3}$ & $<3.00 \times 10^{-3}$ \\
\hline Total metal cations & 21 & 2032 & 2120 & 940 & 397 \\
\hline S & 27.4 & 67.2 & 111.2 & 37.2 & 36.8 \\
\hline $\mathrm{P}$ & 0.13 & 0.84 & 0.29 & - & - \\
\hline TOC $^{\mathrm{a}}$ & 7.3 & 624 & 264 & & 2027 \\
\hline N-tot & & & 130 & & \\
\hline $\mathrm{NH}_{4}-\mathrm{N}$ & & & 100 & & \\
\hline $\mathrm{Cl}^{-}$ & $5.6^{\mathrm{b}}$ & $1100^{\mathrm{c}}$ & & & \\
\hline $\mathrm{HCO}_{3}^{-}$ & & $1000^{c}$ & & & \\
\hline $\mathrm{pH}$ & 5.7 & 7.8 & & & 10.8 \\
\hline
\end{tabular}

\footnotetext{
${ }^{\mathrm{a}}$ Total organic carbon.

${ }^{\mathrm{b}}$ Concentration in an average river water [23].

${ }^{\mathrm{c}}$ Annual mean value.
} 
The leachate from the copper sulphide mine area contained elevated concentrations of $\mathrm{Zn}$ and $\mathrm{Cu}$ compared to uncontaminated stream water and the $\mathrm{pH}$ value was 5.7. However, the metal concentrations were low related to leachates from other acid mine areas (e.g. $[25,26])$. Wastewater was collected from the KM laundry in Gammelstad after washing of overalls used by mine workers from LKAB in 1995. Samples were collected on two different occasions. The wastewater had a high concentration of heavy metals and a high $\mathrm{pH}$ value, 10.8. A summation of all measured cationic ions gave about $20 \mathrm{mg} \mathrm{L}^{-1}$ in the sulphide mine leachate, about $2000 \mathrm{mg} \mathrm{L}^{-1}$ in the landfill leachate and 400 or $950 \mathrm{mg} \mathrm{L}^{-1}$ in the laundry wastewater (Table 2). The concentration of total organic carbon (TOC) was $2000 \mathrm{mg} \mathrm{L}^{-1}$ in the wastewater from the laundry, 260$620 \mathrm{mg} \mathrm{L}^{-1}$ in the landfill leachate and $7 \mathrm{mg} \mathrm{L}^{-1}$ in the leachate from the mine deposit.

\section{Methods}

\subsection{Batch experiments}

Adsorbent and wastewater were mixed in batch experiments in acid-washed $250 \mathrm{~mL}$ glass bottles placed on a shaker for 1 week at room temperature. After filtration through a $45 \mu \mathrm{m}$ glass fibre filter, the effluent was collected and analysed for metals and TOC. Amount of adsorbent added to $100 \mathrm{~mL}$ wastewater was $40 \mathrm{~g} \mathrm{~L}^{-1}$ except for the peat granules, where $20 \mathrm{~g} \mathrm{~L}^{-1}$ was used. The amounts of metals leached from the adsorbents in distilled water were determined with the same method. In metal concentrations given after contact with the adsorbents in the batch experiments, the amounts of metals leached in distilled water were deducted.

\subsection{Column experiments}

In the column experiments a glass column, i.d. $30 \mathrm{~mm}$, with a plastic net at the bottom covered with a glass fibre filter, was used. Experiments were performed with peat samples alone or in combination with glauconite or clinoptilolite. Peat particles smaller than $45 \mu \mathrm{m}$ were removed through a sieve. The adsorbents were placed into the columns, $0.5 \mathrm{~g}$ peat with a height of approximately $3.0 \mathrm{~cm}$ or $3.0 \mathrm{~g}$ mineral giving a height of approximately $0.5 \mathrm{~cm}$, covered by $0.5 \mathrm{~g}$ peat. A glass fibre filter was placed above the peat surface. Sulphide mine leachate and landfill leachates, respectively, were percolated through the peat or peat/mineral filter. No column experiments were performed with the laundry wastewater, since pre-experiments showed that it caused the peat bed to clog. The water flow was regulated to achieve a contact time of $20 \mathrm{~min}$. The effluent was collected in $4 \times 25 \mathrm{~mL}$ fractions, giving a total volume of $100 \mathrm{~mL}$, which correspond to 5 bed volumes. This volume is enough to describe the metal removal efficiency of the peat and peat/mineral samples.

\subsection{Metal analysis}

Metal concentrations were measured with ICP-AES or ICP-MS technique after acidification with nitric acid $(1 \mathrm{~mL}$ per $100 \mathrm{~mL})$. The samples were analysed by two laboratories, SGAB in Luleå and the Environmental Research Laboratory at the Department of Forest Ecology, SLU in Umeå. The metal analyses at the laboratories were compared for the initial metal concentrations in the landfill and sulphide mine leachate samples collected in 1995 and the deviation was found to be minor. In samples measured by SGAB, the deviation was given for each analysis (Table 3). A deviation of $<5 \%$ for all elements was given for samples analysed by the Environmental Research Laboratory. Nitrogen analyses were conducted for the landfill leachate samples at the Laboratory for Chemistry and Biomass at SLU in Umeå.

\subsection{Speciation calculations}

Calculations of the speciation of $\mathrm{Cu}, \mathrm{Zn}, \mathrm{Ni}, \mathrm{Cd}$ and $\mathrm{Pb}$ in the wastewaters were performed using the chemical equilibrium model WHAM-W [27]. Initial metal and sulphur concentrations presented in Table 2

Table 3

Percentage of error in analyses of filtrates from the batch experiment performed by SGAB

\begin{tabular}{llllll}
\hline & $\mathrm{Cu}$ & $\mathrm{Zn}$ & $\mathrm{Ni}$ & $\mathrm{Cd}$ & $\mathrm{Pb}$ \\
\hline Sphagnum Acutifolia peat & $1-3$ & 1 & $1-18$ & $6-9$ & $0-4$ \\
Sphagnum Cuspidata peat & $1-5$ & $1-2$ & $2-4$ & $7-25$ & $1-5$ \\
Carex peat & $1-4$ & $1-4$ & $2-8$ & $6-14$ & $4-11$ \\
Glauconite & $1-5$ & $0.1-8$ & $2-6$ & $4-11$ & $2-4$ \\
Clinoptilolite & $1-3$ & $3-7$ & $2-15$ & $7-46$ & $2-5$ \\
SSAB flue dust & $1-12$ & $5-16$ & $2-8$ & $3-12$ & $2-5$ \\
\hline
\end{tabular}


were used in the calculations. All sulphur was assumed to occur as $\mathrm{SO}_{4}^{2-}$. The $\mathrm{CO}_{2}$ pressure of the atmosphere, $10^{-3.5} \mathrm{~atm}$, was used in the calculations for the sulphide mine and laundry wastewater. Nitrogen and TOC were not included in the calculations. Both $\mathrm{NH}_{3}$ and organic acids present in the wastewaters can form complexes with the metal ions. Therefore, a speciation including these elements was performed for the landfill leachate, having a high nitrogen and TOC concentration. The composition of the TOC fraction was unknown but acetic acid is one of a large number of different organic compounds found in large quantities in some landfill leachate samples [28]. A speciation of $\mathrm{Cu}$ and $\mathrm{Zn}$ in a solution of $\mathrm{Cl}^{-}, \mathrm{SO}_{4}^{2-}, \mathrm{HCO}_{3}^{-}, \mathrm{N}$-tot and acetic acid was performed at varying acetic acid concentrations, using the programme SOLGASWATER [29]. Concentrations according to the concentration in the landfill leachate (Table 2) were used in the calculations.

\section{Results}

\subsection{Speciation of metal ions}

According to the speciation calculations, the metal ions are mainly found as aquo complexes ('free metal ions'), $\mathrm{M}_{x}\left(\mathrm{H}_{2} \mathrm{O}\right)_{y}^{n+}$ in the sulphide mine leachate but occur as metal complexes in the landfill leachate and laundry wastewater (Table 4). In the landfill leachate metal carbonate complexes dominated, while a minor part of the metals occurred as free ions. Copper and zinc should occur to a high extent as positively charged complexes with $\mathrm{HCO}_{3}^{-}$according to the calculation presented in Table 4. A speciation of the landfill leachate including nitrogen and acetic acid showed that the main part of the nitrogen occurred as ammonium ions and only a minor part formed $\mathrm{NH}_{3}$ complexes with the metals. At low concentration of acetic acid $\mathrm{Cu}$ and $\mathrm{Zn}$ formed carbonate complexes, while at high concentrations organic acid complexes dominated (Fig. 1). No free $\mathrm{Cu}$ ions were available according to the calculation, while $\mathrm{Zn}$ occurred to some extent as free ions. In the laundry wastewater, which had a high $\mathrm{pH}$ and TOC, a very brief calculation of the speciation, without organic material, showed that all metal ions except $\mathrm{Cd}$ should occur as metal hydroxides or carbonates.

\subsection{Batch experiments}

The total metal removal varied between the different wastewaters tested (Fig. 2). The removal of metals was low with all adsorbents in the landfill leachate, while a higher removal was achieved in the sulphide mine leachate and the laundry wastewater. The landfill leachate with its high $\mathrm{pH}$ and ionic strength seems to have dissolved metals initially bound to the adsorbents.

In the sulphide mine leachate, where the metal ion occurred to a high extent as free ions, a high removal of $\mathrm{Cu}$ was reached with all adsorbents tested according to Table 5. Zinc was also removed to a rather high extent (Table 5). The $\mathrm{pH}$ value in the sulphide mine leachate, initially $\mathrm{pH}$ 5.7, decreased when the leachate was mixed with the peat samples. At the end of the experiment, $\mathrm{pH}$ had decreased to 3.6 with the Sphagna sect. Cuspidata

Table 4

Metal speciation $(\%)$ in wastewater calculated by the programme WHAM-W [27]

\begin{tabular}{|c|c|c|c|c|c|}
\hline \multicolumn{2}{|c|}{ Sulphide mine leachate } & \multicolumn{2}{|c|}{ Landfill leachate } & \multicolumn{2}{|c|}{ Laundry wastewater } \\
\hline $\begin{array}{l}\mathrm{Cu}^{2+} \\
\mathrm{CuHCO}_{3}^{+} \\
\mathrm{CuSO}_{4}\end{array}$ & $\begin{array}{r}88 \\
4 \\
9\end{array}$ & $\begin{array}{l}\mathrm{Cu}^{2+} \\
\mathrm{CuHCO}_{3}^{+} \\
\mathrm{CuCO}_{3} \\
\mathrm{Cu}\left(\mathrm{CO}_{3}\right)_{2}\end{array}$ & $\begin{array}{r}1 \\
57 \\
38 \\
4\end{array}$ & $\begin{array}{l}\mathrm{Cu}^{2+} \\
\mathrm{Cu}\left(\mathrm{CO}_{3}\right)_{2}\end{array}$ & $\begin{array}{r}0 \\
100\end{array}$ \\
\hline $\begin{array}{l}\mathrm{Zn}^{2+} \\
\mathrm{ZnSO}_{4}\end{array}$ & $\begin{array}{l}90 \\
10\end{array}$ & $\begin{array}{l}\mathrm{Zn}^{2+} \\
\mathrm{ZnCO}_{3} \\
\mathrm{ZnHCO}_{3}^{+}\end{array}$ & $\begin{array}{l}19 \\
14 \\
65\end{array}$ & $\begin{array}{l}\mathrm{Zn}^{2+} \\
\mathrm{Zn}(\mathrm{OH})_{2} \\
\mathrm{ZnCO}_{3}\end{array}$ & $\begin{array}{r}0 \\
46 \\
53\end{array}$ \\
\hline $\begin{array}{l}\mathrm{Ni}^{2+} \\
\mathrm{NiSO}_{4}\end{array}$ & $\begin{array}{r}91 \\
9\end{array}$ & $\begin{array}{l}\mathrm{Ni}^{2+} \\
\mathrm{NiCO}_{3} \\
\mathrm{NiHCO}_{3}^{+}\end{array}$ & $\begin{array}{r}6 \\
50 \\
43\end{array}$ & $\begin{array}{l}\mathrm{Ni}^{2+} \\
\mathrm{NiCO}_{3}\end{array}$ & $\begin{array}{r}0 \\
100\end{array}$ \\
\hline $\begin{array}{l}\mathrm{Cd}^{2+} \\
\mathrm{CdSO}_{4} \\
\mathrm{CdCl}^{+}\end{array}$ & $\begin{array}{r}88 \\
11 \\
1\end{array}$ & $\begin{array}{l}\mathrm{Cd}^{2+} \\
\mathrm{CdCl}^{+} \\
\mathrm{CdCl}_{2}\end{array}$ & $\begin{array}{r}41 \\
54 \\
4\end{array}$ & $\begin{array}{l}\mathrm{Cd}^{2+} \\
\mathrm{CdOH}^{+} \\
\mathrm{Cd}(\mathrm{OH})_{2}\end{array}$ & $\begin{array}{l}21 \\
34 \\
45\end{array}$ \\
\hline $\begin{array}{l}\mathrm{Pb}^{2+} \\
\mathrm{PbSO}_{4}\end{array}$ & $\begin{array}{l}77 \\
22\end{array}$ & $\begin{array}{l}\mathrm{Pb}^{2+} \\
\mathrm{PbCO}_{3} \\
\mathrm{~Pb}\left(\mathrm{CO}_{3}\right)_{2}^{2-}\end{array}$ & $\begin{array}{r}0 \\
88 \\
11\end{array}$ & $\begin{array}{l}\mathrm{Pb}^{2+} \\
\mathrm{Pb}\left(\mathrm{CO}_{3}\right)_{2}^{2-}\end{array}$ & $\begin{array}{r}0 \\
100\end{array}$ \\
\hline
\end{tabular}

\footnotetext{
${ }^{\mathrm{a}}$ The initial concentrations according to Table 2 were used.
} 

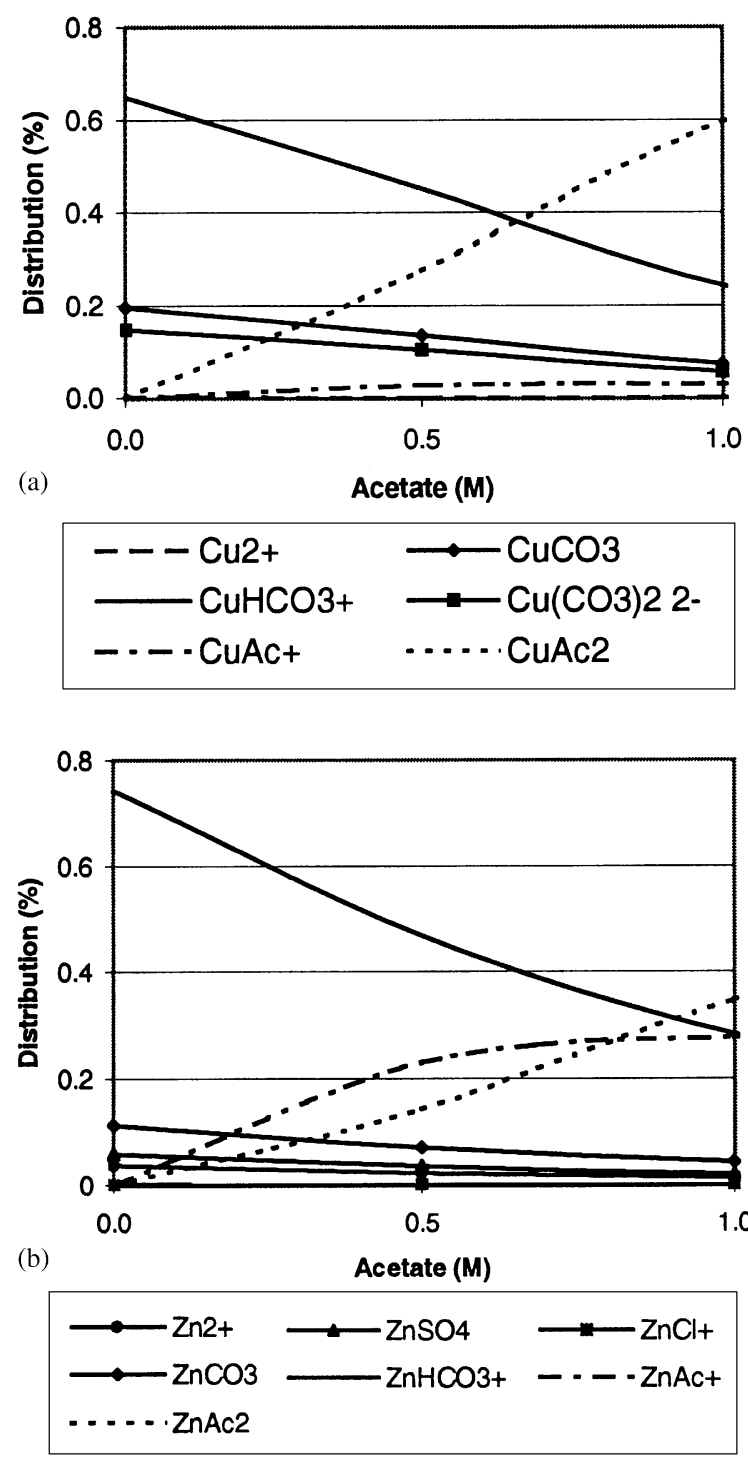

Fig. 1. Distribution of $\mathrm{Cu}$ and $\mathrm{Zn}$ species at increased concentration of acetic acid in landfill leachate calculated by the program SOLGASWATER [29]. The concentrations of $\mathrm{Cu}$, $\mathrm{Zn}, \mathrm{S}, \mathrm{HCO}_{3}^{-}$and $\mathrm{Cl}^{-}$according to Table 2 were used in the calculations. (a) $\mathrm{Cu}$, (b) $\mathrm{Zn}$.

peat, 4.2 with the Sphagna sect. Acutifolia peat, and 4.9 and 5.0 with Carex peat or peat granules, respectively. The peat granules broke up into small particles in the experiment. The $\mathrm{pH}$ value increased to $\mathrm{pH} 7.2$ with glauconite, to 7.3 with clinoptilolite and to 10.3 when the leachate was mixed with flue dust.

Generally, a rather low metal removal was achieved in the landfill leachate (Fig. 2). The $\mathrm{pH}$ value remained at the same level for all adsorbents, due to a high buffering capacity of the leachate. Copper was adsorbed onto the peat samples, while $\mathrm{Zn}$ was released from the Sphagnum
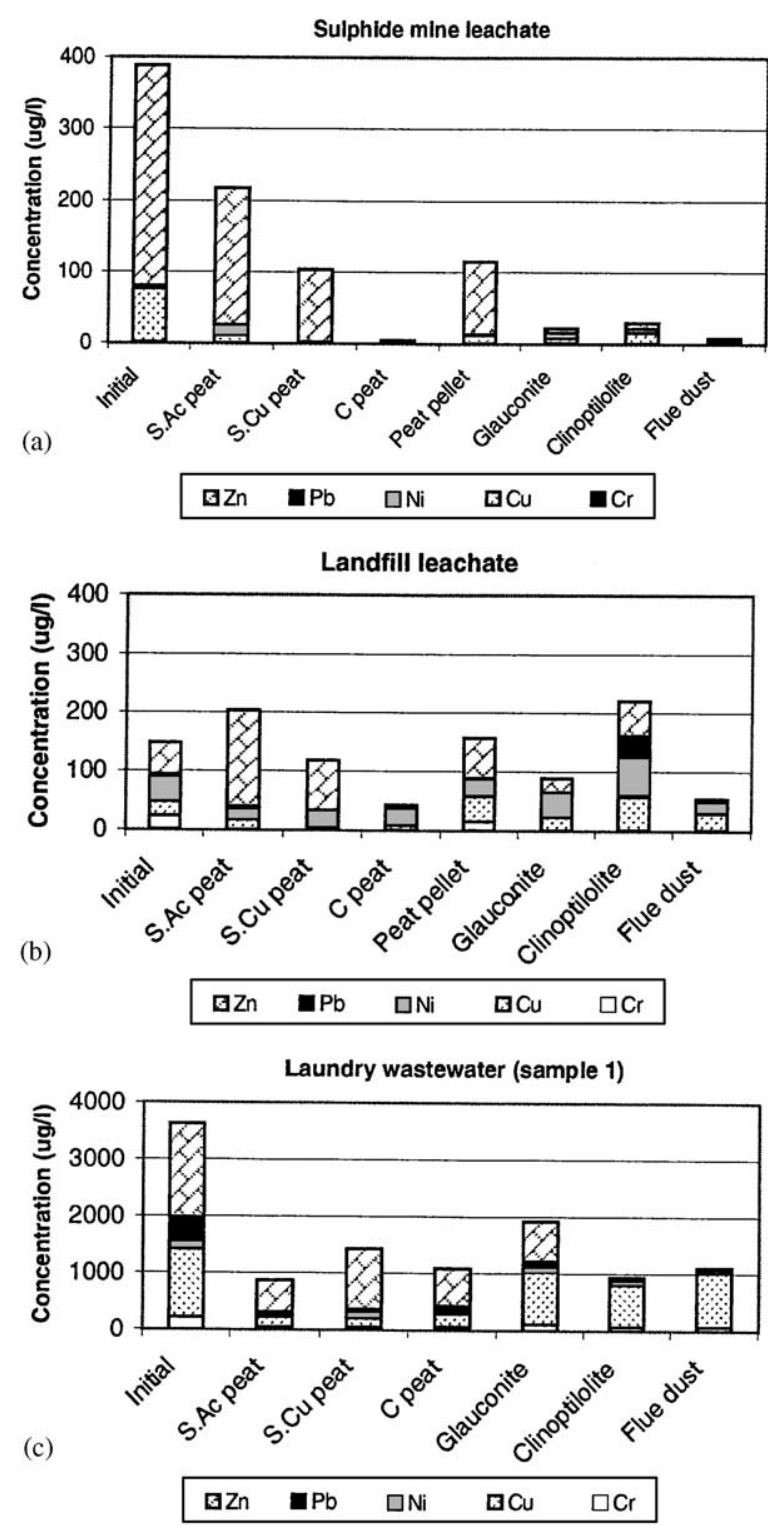

Fig. 2. Metal concentration in wastewater before and after contact with different adsorbents at wastewater/adsorbent ratio $40 \mathrm{~g} \mathrm{~L}^{-1}$ (with exception for peat pellets $20 \mathrm{~g} \mathrm{~L}^{-1}$ ). The amount metal leached from the adsorbents in distilled water were withdrawn.

peat and the peat granules (Table 5). A high $\mathrm{Pb}$ and $\mathrm{Cd}$ removal was achieved in particular using the Carex peat and peat pellet. No metal removal occurred with clinoptilolite.

In the laundry wastewater, a high $\mathrm{Cu}$ removal and a lower $\mathrm{Zn}$ removal was achieved with the peat samples, while the inorganic samples gave a high $\mathrm{Zn}$ removal and a low $\mathrm{Cu}$ removal (Table 5). A high removal of $\mathrm{Cd}, \mathrm{Pb}$ and $\mathrm{Cr}$ was observed with both peat and inorganic samples. 
Table 5

Metal removal (\%) in batch experiments with $40 \mathrm{~g} \mathrm{~L}^{-1}$ organic and inorganic adsorbents

\begin{tabular}{|c|c|c|c|c|c|c|c|c|c|c|c|c|c|c|c|}
\hline & \multicolumn{4}{|c|}{ Sulphide mine leachate } & \multicolumn{5}{|c|}{ Landfill leachate } & \multicolumn{6}{|c|}{ Laundry wastewater (sample 1) } \\
\hline & $\mathrm{Cu}$ & $\mathrm{Zn}$ & $\mathrm{Ni}$ & $\mathrm{Cd}$ & $\mathrm{Cu}$ & $\mathrm{Zn}$ & $\mathrm{Ni}$ & $\mathrm{Cd}$ & $\mathrm{Pb}$ & $\mathrm{Cu}$ & $\mathrm{Zn}$ & $\mathrm{Ni}$ & $\mathrm{Cd}$ & $\mathrm{Pb}$ & $\mathrm{Cr}$ \\
\hline Sphagnum Acutifolia peat & 86 & 38 & - & 56 & 32 & - & 55 & 37 & 41 & 84 & 65 & 60 & 93 & 95 & 81 \\
\hline Sphagnum Cuspidata peat & 100 & 67 & 68 & 97 & 86 & - & 27 & 62 & 65 & 87 & 35 & 15 & 43 & 87 & 79 \\
\hline Carex peat & 100 & 99 & 100 & 93 & 68 & 89 & 28 & 72 & 83 & 81 & 60 & 56 & 13 & 81 & 74 \\
\hline Peat granules ${ }^{\mathrm{a}}$ & 85 & 67 & 77 & 100 & - & - & 27 & 81 & 80 & 76 & 31 & 38 & 88 & 88 & 65 \\
\hline Clinoptilolite & 80 & 98 & - & 47 & - & - & - & - & - & 38 & 97 & 47 & 80 & 97 & 70 \\
\hline Flue dust & 87 & 100 & - & 4 & - & 90 & 50 & 0 & 100 & 21 & 99 & 50 & 80 & 98 & 68 \\
\hline Glauconite & 90 & 98 & - & 39 & 6 & 56 & - & 20 & 88 & 23 & 58 & 35 & 29 & 88 & 49 \\
\hline
\end{tabular}

${ }^{\mathrm{a}}$ Amount of adsorbent used was $20 \mathrm{~g} \mathrm{~L}^{-1}$. Metal release in distilled water not measured. Sample 2 of the laundry wastewater used.

\subsection{Column experiments}

The Carex peat sample removed $88-97 \%$ of $\mathrm{Cu}, \mathrm{Zn}$, $\mathrm{Ni}$ and Cd, while the Sphagnum peat sample removed $70-80 \%$ (Fig. 3). A higher amount of Fe was removed using the Sphagnum peat sample compared to the Carex peat sample. A slight improvement in metal removal was achieved by treating the sulphide mine leachate with Sphagnum peat combined with glauconite in the column experiment (Table 6). The TOC concentration decreased when the Sphagnum peat sample was used, while outwash of TOC occurred from the Carex peat sample. In the sulphide mine leachate, the Sphagnum peat sample adsorbed twice the amount of cations that was adsorbed by the Carex peat sample (Table 7) but the cations adsorbed were mainly $\mathrm{Ca}$ ions.

In the landfill leachate, the $\mathrm{Cu}$ concentration was reduced by $20 \%$ after treatment with Sphagnum peat (Fig. 4). Zinc was initially released from the Sphagnum peat surface but then the concentration decreased by about $50 \%$ in the column experiment. Cadmium was released from the Sphagnum peat. The concentration of TOC remained unchanged. Only a minor improvement or no improvement at all, in the metal adsorption was achieved with the combination of Sphagnum peat with glauconite, or clinoptilolite to the peat sample. The total amounts of adsorbed cations were slightly higher onto the Sphagna sect. Acutifolia peat sample, $1.7 \mathrm{mmol} \mathrm{g}^{-1}$, compared to the Sphagna sect. Cuspidata peat sample, $1.6 \mathrm{mmol} \mathrm{g}^{-1}$ (Table 7). The difference depended on a higher adsorption of $\mathrm{Ca}^{2+}$ to the Sphagna sect. Acutifolia peat sample.

\section{Discussion}

\subsection{The sulphide mine leachate}

The metal ions mainly occurred as free metal ions in the sulphide mine leachate according to the speciation calculated (Table 4). Pettersson et al. [30] examined the metal speciation in surface water rich in humic and fulvic acids downstream from a deposit with sulphide mine waste. They found that $\mathrm{Zn}$ and $\mathrm{Cd}$ predominantly existed as free ions and minor fractions as neutral sulphate and carbonate complexes. $\mathrm{Cu}$ was found to form humic and fulvic complexes except at low $\mathrm{pH}$ and high concentrations of $\mathrm{Al}$ and $\mathrm{Fe}$, where the humic and fulvic acid sites were occupied by trivalent $\mathrm{Al}$ and $\mathrm{Fe}$ ions. Generally, a high metal removal was reached with all adsorbents tested in the sulphide mine leachate in the present study (Fig. 2). A model describing $\mathrm{Cu}$ and $\mathrm{Zn}$ adsorption onto Sphagnum and Carex peat at various $\mathrm{pH}$ values and ionic strength ( $\mathrm{Ca}$ and $\mathrm{Na}$ concentrations) determined in a factorial experiment [10] predicted a high $\mathrm{Cu}$ and lower $\mathrm{Zn}$ removal in the sulphide mine leachate. The reason for the predicted $\mathrm{Zn}$ removal being lower than that obtained was probably due to a higher competition between $\mathrm{Cu}$ and $\mathrm{Zn}$ for adsorption sites in the factorial experiment than in the leachate due to the lower amount of adsorbent used $\left(1.7 \mathrm{~g} \mathrm{~L}^{-1}\right.$ compared to $\left.40 \mathrm{~g} \mathrm{~L}^{-1}\right)$.

A higher $\mathrm{Zn}$ removal was obtained with Carex peat (99\% in batch and $97 \%$ in column experiments) than with Sphagnum peat $(38-67 \%$ in batch and $77 \%$ in column experiments). The removal of $\mathrm{Zn}$ was found to increase significantly with $\mathrm{pH}$ [10]. The $\mathrm{pH}$ value in the Sphagnum peat batches was low, between 3.4 and 4.2 , while it was nearly 5 in the Carex peat sample. However, a higher $\mathrm{Cu}$ adsorption capacity of untreated samples of Sphagnum peat compared to Carex peat was found at pH 4.7 [8]. The higher $\mathrm{Zn}$ adsorption onto Carex peat compared to Sphagnum peat can probably be explained by the higher $\mathrm{pH}$ value in the Carex peat batches. The result could also indicate a higher affinity for Carex peat. A lower adsorption of $\mathrm{Zn}$ in particular was found for the Sphagna sect. Acutifolia peat, giving a lower $\mathrm{pH}$ in the batches compared to the Sphagna sect. Cuspidata peat (Table 5). The adsorption of $\mathrm{Cu}$ onto peat was found to be less dependent on $\mathrm{pH}$ than the adsorption of 

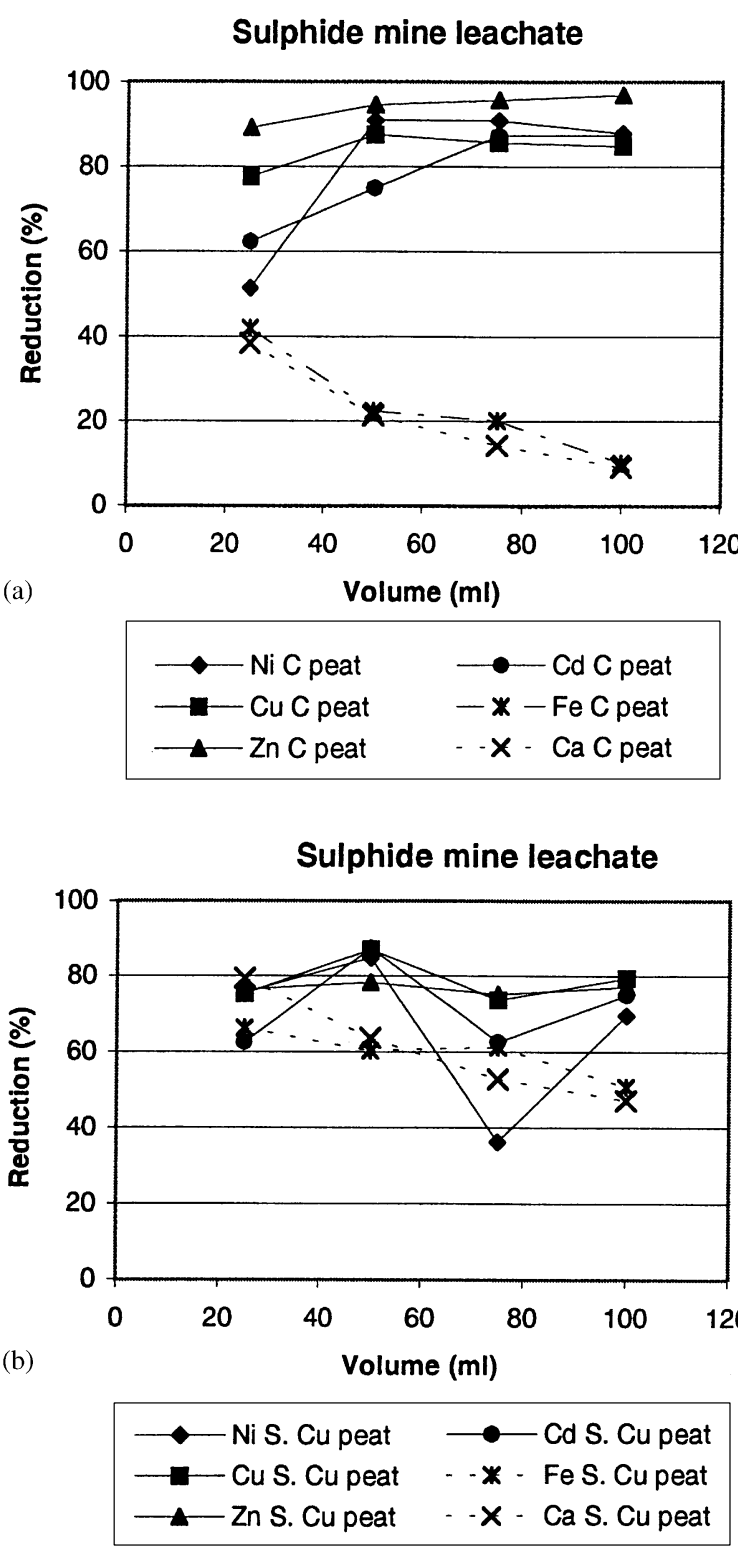

Fig. 3. Removal (\%) of $\mathrm{Ni}, \mathrm{Cu}, \mathrm{Zn}, \mathrm{Cd}, \mathrm{Fe}$ and $\mathrm{Ca}$ in the sulphide mine leachate in column experiments. (a) Sphagnum Cuspidata peat, (b) Carex peat.

$\mathrm{Zn} \mathrm{[10].} \mathrm{In} \mathrm{the} \mathrm{sulphide} \mathrm{mine} \mathrm{leachate,} \mathrm{the} \mathrm{adsorbed}$ amount of $\mathrm{Cu}$ was almost the same onto the Sphagnum and Carex peat samples. Removal rates obtained were $100 \%$ in batch and $80-85 \%$ in column experiments.

In this study, poorly humified Carex peat was a better adsorbent for heavy metals than poorly humified Sphagnum peat, while the Sphagnum peat sample adsorbed a higher amount of $\mathrm{Ca}$ (Table 7). Calcium ions preferentially form complexes with ligands containing oxygen as a donor atom, while $\mathrm{Zn}$ ions co-ordinate preferentially with ligands containing $\mathrm{N}, \mathrm{P}$ or $\mathrm{S}$ as donor atoms [31]. A higher uronic acid content and a lower N, $\mathrm{P}$ and S content has been found in Sphagnum peat than in Carex peat. The Carex peat sample initially contained a higher total amount of $\mathrm{Ca}$ and $\mathrm{Fe}$ (Table 1). Exchangeable $\mathrm{Ca}$ ions can more easily be replaced by heavy metals compared to hydrogen ions [32,33]. A lower removal of $\mathrm{Ca}$ and $\mathrm{Fe}$ was reached in the column experiment with Carex peat than with Sphagnum peat (Fig. 3).

Adsorption isotherms for $\mathrm{Cu}, \mathrm{Zn}, \mathrm{Ni}, \mathrm{Cd}$ and $\mathrm{Fe}$ in mixture were determined previously [8] onto the Sphagna sect. Acutifolia peat sample. The adsorbed amount of these ions in the column experiment (not achieving maximum adsorption) was about $1 / 10$ of the amount predicted for each metal (Table 7).

\subsection{The landfill leachate}

The calculation of the speciation of $\mathrm{Cu}$ and $\mathrm{Zn}$ in the landfill leachate showed that most of the metals in the leachate occurred as carbonate complexes or were bound to the organic fraction in the leachate. The carbonate complexes formed were to a high extent positively charged (Table 4). At increased concentration of acetic acid, used as an example of organic compounds found in landfill leachates, a higher amount of organic acid complexes were formed while the amount of carbonate complexes decreased. A lower metal adsorption was achieved in the sulphide mine leachate with all adsorbents tested in both batch (Fig. 2) and column experiments (Table 6). The reason was most probably that the metal ions to a high extent were bound to the organic fraction in the leachate. High $\mathrm{Na}$ concentration and high ionic strength in the landfill leachate can also contribute to a low metal adsorption, due to competition with the heavy metals for adsorption sites.

In the column experiment, $\mathrm{Zn}$ was initially released from the Sphagnum peat surface but later the concentration decreased by about $50 \%$ in the wastewater. In the batch experiment too, $\mathrm{Zn}$ was released from the Sphagnum peat samples, while the Carex peat sample adsorbed $\mathrm{Zn}$ to a high extent. Zinc has previously been observed [1] to be exchanged by other ions in treating landfill leachate with peat. Ringqvist and Öborn [10] found that $\mathrm{Zn}$ was bound to Carex peat to a higher extent than to Sphagnum peat at the $\mathrm{pH}$ and $\mathrm{Ca}$ and $\mathrm{Na}$ concentrations prevailing in the landfill leachate. A minor increase in metal removal was obtained in the column experiment adding clinoptilolite or glauconite to the peat sample.

In the column experiment a slightly higher total cation adsorption was reached onto Sphagna sect. Acutifolia peat compared to onto Sphagna sect. Cuspidata peat (Table 7), earlier found to have a higher metal adsorption capacity [34]. The total amount of cations 
Table 6

Metal and TOC removal (\%) in column experiments with sulphide mine and landfill leachate, when approximately 5 bed volumes $(100 \mathrm{~mL})$ leachate had passed through the column

\begin{tabular}{|c|c|c|c|c|c|c|c|c|}
\hline \multirow[b]{2}{*}{ Metal ion } & \multicolumn{4}{|c|}{ Sulphide mine leachate } & \multicolumn{4}{|c|}{ Landfill leachate } \\
\hline & $\begin{array}{l}\text { Sphagnum } \\
\text { Cuspidata } \\
\text { peat }\end{array}$ & $\begin{array}{l}\text { Sphagnum } \\
\text { Cuspidata peat } \\
\text { and glauconite }\end{array}$ & Carex peat & $\begin{array}{l}\text { Carex } \\
\text { peat and } \\
\text { clinoptilolite }\end{array}$ & $\begin{array}{l}\text { Sphagnum } \\
\text { Acutifolia } \\
\text { peat }\end{array}$ & $\begin{array}{l}\text { Sphagnum } \\
\text { Acutifolia peat } \\
\text { and glauconite }\end{array}$ & $\begin{array}{l}\text { Sphagnum } \\
\text { Acutifolia } \text { peat } \\
\text { and clinoptilolite }\end{array}$ & $\begin{array}{l}\text { Sphagnum } \\
\text { Cuspidata } \\
\text { peat }\end{array}$ \\
\hline $\mathrm{Fe}$ & 51 & 47 & 10 & 23 & 55 & 45 & 59 & 50 \\
\hline $\mathrm{Zn}$ & 77 & 94 & 97 & 98 & 55 & 46 & 53 & 56 \\
\hline $\mathrm{Cu}$ & 80 & 92 & 85 & 86 & 21 & 20 & 41 & 15 \\
\hline $\mathrm{Ni}$ & 70 & 91 & 88 & 97 & 15 & 19 & 37 & 17 \\
\hline $\mathrm{Cd}$ & 75 & 88 & 88 & 88 & -50 & -17 & 23 & -33 \\
\hline TOC & 10 & 9 & -72 & 0 & 2 & 11 & - & 2 \\
\hline
\end{tabular}

Table 7

Amount of cations adsorbed onto peat $\left(\mathrm{mmol} \mathrm{kg}^{-1}\right)$ in column experiments, when approximately five bed volumes $(100 \mathrm{~mL}) \mathrm{of} \mathrm{leachate}$ had passed through the column

\begin{tabular}{|c|c|c|c|c|c|c|c|c|}
\hline & \multicolumn{4}{|c|}{ Sulphide mine leachate } & \multicolumn{4}{|c|}{ Landfill leachate } \\
\hline & \multicolumn{2}{|c|}{ Sphagnum sect. Cuspidata peat } & \multicolumn{2}{|c|}{ Carex peat } & \multicolumn{2}{|c|}{ Sphagnum sect. Cuspidata peat } & \multicolumn{2}{|c|}{ Sphagnum sect. Acutifolia peat } \\
\hline & Adsorbed & Released & Adsorbed & Released & Adsorbed & Released & Adsorbed & Released \\
\hline $\mathrm{Ca}$ & 39.9 & & 13.7 & & 573.9 & & 648.7 & \\
\hline $\mathrm{Na}$ & & 21.8 & & 7.0 & 695.9 & & 739.4 & \\
\hline K & & 1.3 & 1.3 & & 306.9 & & 255.8 & \\
\hline $\mathrm{Mg}$ & & 14.0 & & 6.2 & 41.2 & & 82.3 & \\
\hline $\mathrm{Fe}$ & 1.4 & & 0.5 & & 7.2 & & 7.2 & \\
\hline $\mathrm{Mn}$ & 1.6 & & 1.1 & & 0.95 & & 1.0 & \\
\hline $\mathrm{Al}$ & 0.7 & & 1.1 & & 0.11 & & 0.03 & \\
\hline Total $^{\mathrm{a}}$ & 43.7 & 37.0 & 17.7 & 13.1 & 1626 & & 1734 & \\
\hline
\end{tabular}

${ }^{\mathrm{a}}$ Total amount of metal cations adsorbed released.

adsorbed agreed rather well with maximum metal adsorption $\left(51 \mathrm{mg} \mathrm{g}^{-1}\right)$ according to the Langmuir isotherm determined in a mixed solution of $\mathrm{Cd}, \mathrm{Cu}$, $\mathrm{Fe}, \mathrm{Ni}$ and $\mathrm{Zn}$ for the Sphagna sect. Acutifolia peat sample [8]. Lidkea [3] reported the same level $\left(55 \mathrm{mg} \mathrm{g}^{-1}\right)$ for metal adsorption from a landfill leachate onto Sphagnum peat. Only a minor correlation between adsorption isotherms and column studies with landfill leachate was found by McLellan and Rock [35], due to the complexity of the leachates. Peat was not found to be capable of removing metals to acceptable levels for direct discharge, but was sufficient for a pre-treatment (or polishing) process.

\subsection{The laundry wastewater}

In the laundry wastewater the metal ions formed carbonate and hydroxide complexes according to the calculation (Table 4) or bound to the organic fraction in the wastewater. Despite this, a rather high metal removal was achieved in the batch experiment. It was observed that the wastewater contained suspended particles. The reason for the high metal removal is probably that the metals were bound to these particles and withdrawn during the filtration operation.

\subsection{Metal removal and wastewater composition}

The wastewater composition was of great importance for metal removal efficiency, mainly due to the metal speciation. A high degree of metal removal was reached in the sulphide mine leachate, containing mainly free metal ions. A rather high metal removal rate was also reached in the laundry wastewater. The metal ions were probably removed bound to particles withdrawn from the wastewater. The lowest metal removal, and a release of metals initially bound to the adsorbents, occurred in the landfill leachate. A high ionic strength and the 


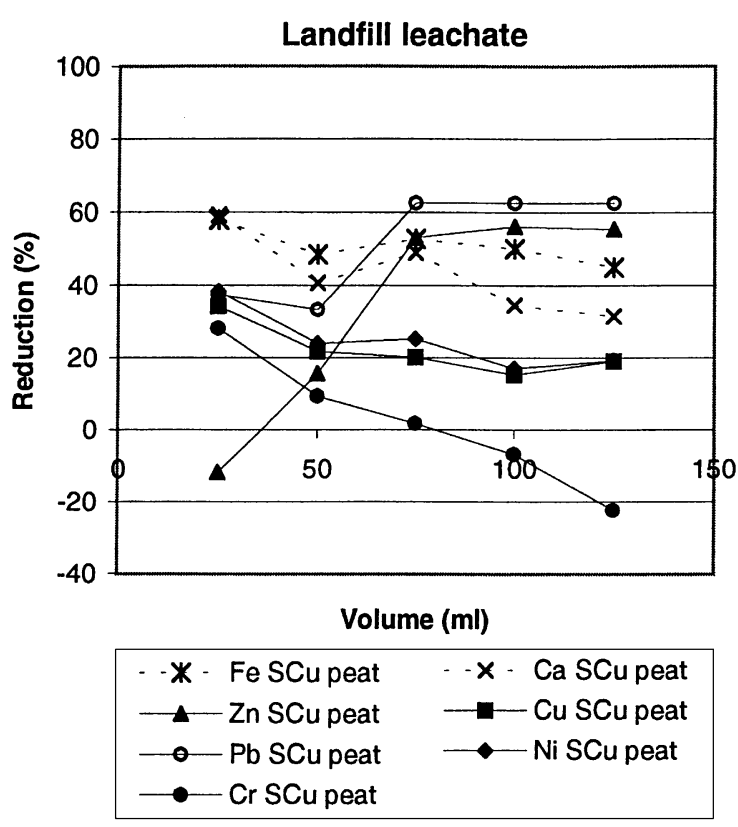

Fig. 4. Removal (\%) of $\mathrm{Ni}, \mathrm{Cu}, \mathrm{Zn}, \mathrm{Cd}, \mathrm{Fe}$ and $\mathrm{Ca}$ in the landfill leachate in column experiments. (a) Sphagnum Cuspidata peat, (b) Carex peat.

metals forming carbonate and organic complexes could explain the result achieved. Generally, the combination of glauconite or clinoptilolite with the peat samples gave a minor improvement in metal removal in column experiments. The total amount of cations adsorbed in column experiments with landfill leachate agreed rather well with the maximum adsorption determined in previous studies. The previously recorded higher increase of metal adsorption onto Carex peat than onto Sphagnum peat with increased $\mathrm{pH}$ values to a high extent explained the slightly higher adsorption of heavy metals onto Carex peat than onto Sphagnum peat. A higher affinity for $\mathrm{Zn}$ adsorption onto Carex peat than onto Sphagnum peat was indicated. The Sphagnum peat sample adsorbed a higher amount of $\mathrm{Ca}$. The differences between the peat types has been attributed to the fact that Carex peat has higher S, N and P content, while Sphagnum peat has a higher uronic acid content.

\section{Conclusion}

The wastewater composition was of great importance for metal removal efficiency, mainly explained by the calculated metal speciation.

A high metal removal was achieved in the sulphide mine leachate, where the metal ions to a large extent occurred as free ions. The peat samples decreased the
$\mathrm{pH}$ in the leachate, Sphagnum peat to a higher extent than Carex peat. A higher metal removal was reached with Carex peat.

The heavy metal ions in the landfill leachate were to a large extent complex-bound due to a high $\mathrm{pH}$, carbonate and TOC concentration. A low metal removal was achieved. The leachate, high in ionic strength, also seems to have dissolved metal initially bound to the adsorbents.

A high metal removal was reached in the laundry wastewater, which was high in $\mathrm{pH}$ and TOC concentration. The metals were probably bound to suspended particles and withdrawn during the filtration operation.

A rather high metal removal from wastewater was generally found using peat as the adsorbent compared to the inorganic adsorbents investigated. Only minor improvement, or no improvement, was observed when peat was combined with clinoptilolite or glauconite in column experiments.

\section{Acknowledgements}

Valuable comments from Lars Lövgren on the calculation of metal species in the wastewater are gratefully acknowledged. Financial support was provided by the Swedish Waste Research Council and the Swedish University of Agricultural Sciences.

\section{References}

[1] Cameron RD. Treatment of a complex landfill leachate with peat. Can J Civ Eng 1978;5:83-7.

[2] Coupal B, Lalancette JM. The treatment of waste waters with peat moss. Water Res 1976;10:1071-6.

[3] Lidkea TR. Treatment of sanitary landfill leachate with peat. Vancouver, Canada: The University of British Columbia, 1974.

[4] Rock CA, Fiola JW, Greer TF, Woodward FE. Potential of Sphagnum peat to remove metals from landfill leachate. J N Engl Water Pollut Control Assoc 1985;19:32-47.

[5] Lapakko K, Eger P. Trace metal removal from stockpile drainage by peat. Inf Circle-US Bur Mines 1988;1: 291-300.

[6] Lyons HJ, Reidy TJ. The use of peat in treating landfill leachate. In: Hayes MHB, Wilson WS, editors. Humic Substances in Soils, Peats and Waters: Health and Environmental Aspects. Cambridge: Royal Society of Chemistry, 1997. p. 475.

[7] McLellan J, Rock CA. The application of peat in enviromental pollution control; a review. Int Peat $\mathbf{J}$ 1986;1:1-14.

[8] Fattahpour Sedeh I, Igsell P, Ringqvist L, Lindström EB. Comparison of metal adsorption properties and determination of metal adsorption capacities of different peat samples. Resource Environ Biotechnol 1996;1:111-28. 
[9] Bergner K, Ringqvist L, Igsell P. Charge density in peat and peat particle size fractions and its relation to the botanical origin and degree of decomposition. In: Ringqvist L. Peat as metal trap for wasterwater. Acta Universitatis Agriculturae Sveclae, Agraria 226. Doctoral thesis, Swedish University of Agricultural Science, Umeå 2000.

[10] Ringqvist L, Öborn I. Copper and zinc adsorption onto poorly humified Sphagnum and Carex peat. Water Res 2002; in press.

[11] Wu L, Sun Z, Forsling W. Characterization and investigation on the sorption behaviors of SSAB fine dust. Luleå: Luleå University of Technology, 1996.

[12] Papadopoulos A, Kapetanios EG, Loizidou M. Studies on the use of clinoptilolite for ammonia removal from leachates. J Environ Sci Health, Part A 1996;31:211-20.

[13] Loizidou M, Haralambous KJ, Loukatos A. Natural zeolites and their ion-exchange behavior towards chromium. J Environ Sci Health, Part A 1992;A27:1759-69.

[14] Papachristou P, Haralambous KJ, Loizidou M, Spyrellis N. Studies on the nickel removal from aqueous solutions. J Environ Sci Health, Part A 1993;A28:135-42.

[15] Smith EH, Lu W, Vengris T, Binkiene R. Sorption of heavy metals by Lithuanian glauconite. Water Res 1996;30:2883-92.

[16] Spoljaric N, Crawford WA. Removal of contaminants from landfill leachates by filtration through glauconitic greensand. Environ Geol 1978;2:359-63.

[17] Bohlin E, Hämäläinen M, Sundén T. Botanical and chemical characterization of peat using multivariate methods. Soil Sci 1989;147:252-63.

[18] Bohlin E. Botanical composition of peat. Implications on chemical, microbiological and physical properties. Dissertation, Department of Forest Ecology, Swedish University of Agricultural Sciences, 1993.

[19] Clymo RS. Ion exchange in Sphagnum and its relation to bog ecology. Ann Bot 1963;27:309-24.

[20] Spearing AM. Cation-exchange capacity and galacturonic acid content of several species of Sphagnum in Sandy Ridge Bog, Central New York State. Bryologist 1972;75:154-8.

[21] Aho M, Tummavuori J. The ion exchange properties of peat Part V: ion exchange properties of some Sphagnum peats. Suo 1984;35:67-73.

[22] Bohlin E, Hämäläinen M. Multivariate evaluation of the significance of quantitative botanical analysis in peat characterization. Anonymous Proceedings of the VIII
International Peat Congress. International Peat Society, Leningrad, 1988. p. 211.

[23] Stumm W, Morgan JJ. Aquatic chemistry: chemical equilibria and rates in natural waters, 3rd ed. New York: Wiley, 1987.

[24] Öhlander B, Ljungberg J. Acid mine drainage at the Laver Mine, Southern Norrbotten. In: Lövgren L, editor. Workshop on Retention and Mobilization of Heavy Metals in Waste Deposits and Soils, October 18-20, 1994. Swedish Waste Research Council, Stockholm, 1995. p. 22.

[25] Banks D, Younger PL, Arnesen R-T, Iversen ER, Banks SB. Mine-water chemistry: the good, the bad and the ugly. Environ Geol 1997;32:157-74.

[26] Herbert Jr RB. Metal transport in groundwater contaminated by acid mine drainage. Nordic Hydrol 1994;25: 193-212.

[27] Tipping E. WHAM - a chemical equilibrium model and computer code for waters, sediments, and soils incorporating a discrete site/electrostatic model of ion-binding by humic substances. Comput Geosci 1994;20:973-1023.

[28] Öman C. Emissions of organic compounds from landfills Diss. Department of civil and environmental engineering. Stockholm: Royal Institute of Technology, 1998.

[29] Eriksson G. An algorithm for the computation of aqueous multi-component, multiphase equilibria. Anal Chim Acta 1979;112:375-83.

[30] Pettersson C, Håkansson K, Karlsson S, Allard B. Metal speciation in a humic surface water system polluted by acidic leachates from a mine deposit in Sweden. Water Res 1993;27:863-71.

[31] Stevensson FJ. Umus chemistry: genesis, composition, reactions, 2nd ed. New York: Wiley, 1994.

[32] Wolf A, Bunzl K, Diesl F. The effect of $\mathrm{Ca}^{2+}$-ions on the adsorption of $\mathrm{Pb}^{2+}, \mathrm{Cu}^{2+}$, and $\mathrm{Zn}^{2+}$ by humic substances. Chemosphere 1977;5:207-13.

[33] Zhipei Z, Junlu Y, Zenghui W, Piya C. A preliminary study of the removal of $\mathrm{Pb}^{2+}, \mathrm{Cd}^{2+}, \mathrm{Zn}^{2+}, \mathrm{Ni}^{2+}$ and $\mathrm{Cr}^{6+}$ from wastewater with several Chinese peats. 7th International Peat Congress, vol. 3, Dublin, Ireland, June 18-23, 1984. p. 147-52.

[34] Aho M. The ion exchange and adsorption of Sphagnum peat under acid conditions. Dissertation, Department of Chemistry, University of Jyväskylä, Jyväskylä, 1986.

[35] McLellan JK, Rock CA. Pretreating landfill leachate with peat to remove metals. Water Air Soil Pollut 1988;37: 203-15. 